Article

\title{
Climatic Design and Changing Social Needs in the Tropics: A Case Study in Kuching, Sarawak
}

\author{
Elizabeth Karol ${ }^{\dagger, *}$ and Vincent Voon Chin Lai ${ }^{\dagger}$ \\ School of Built Environment, Curtin University, GPO Box U1987, Perth WA 6845, Australia; \\ E-Mail: voonchin.lai@curtin.edu.au
}

$\dagger$ These authors contributed equally to this work.

* Author to whom correspondence should be addressed; E-Mail: e.karol@curtin.edu.au; Tel.: +61-8-9266-7260; Fax: +61-8-9266-2711.

Received: 22 May 2014; in revised form: 21 August 2014 / Accepted: 26 August 2014 /

Published: 12 September 2014

\begin{abstract}
On the periphery of most urban centres in the tropics, many new houses are being constructed in previously rural areas. However, the design of these houses shows little respect for local climate or local lifestyle, as they are now developer-constructed brick-and-concrete houses on smaller lots rather than community-built housing on large lots. This paper proposes a set of design strategies that acknowledges the particular needs related to climate and changing lifestyle in these tropical zones. Using case study methodology, the design strategies are tested on a prototype for an actual site in Tapah Village on the periphery of Kuching, Sarawak. In order to gauge the thermal performance of the prototype it was thermally simulated. The thermal simulation of the prototype showed that temperatures generally remained within an acceptable range without air-conditioning. An informal workshop was held in Tapah to gauge social acceptance of the design strategies. The prototype demonstrated that specific design strategies, some based on traditional designs, are essential in the tropics in order to minimise the need for air conditioning. These design strategies were acknowledged as important by the local community, although there was concern about the potential increase in the capital cost of such housing.
\end{abstract}

Keywords: urbanization; design strategies; housing in the tropics; climatic design 


\section{Introduction}

Many developing countries are situated within the tropics. These countries are experiencing economic growth and rapid urbanization. In Asia, the urban population is increasing by 37 million each year, and 1000 hectares of agricultural land are being converted to urban use each day [1]. Consequently, there is an unprecedented demand for housing, particularly on the outer fringes of cities.

The people occupying housing on the urban fringe choose to live there because it is within reach of their city workplaces and is more affordable than in the city proper. However, there is significant time spent in commuting to work, which means that these urban fringe dwellers have long working days away from home. This leads to a disengagement from neighbours [2] and removes the option of community-built housing that was the norm in these previously rural communities.

In the case of Sarawak, the housing stock available in the peripheral urban areas is becoming increasingly unaffordable, as it is mostly built by housing development companies for the upper end of the housing market [3]. The aim of such development companies is to maximise profits from construction rather than to build suitable housing. Deemed to be a luxury, climatic design concerns are neglected and as a result, "brick-boxes" with large areas of glazing are being built.

In the tropics, these sealed-up "brick-boxes" cannot be naturally cooled to make them livable. This is due to the small diurnal outdoor temperature range in the tropics, which makes any attempts at passive night cooling of thermally massive constructions ineffectual. These "brick-box" structures can only be comfortably occupied with artificial cooling. Thus, developers pass the on-going cost of operating these houses with air-conditioning on to the occupants. Further, there is no regard for the long-term consequences of air conditioning, which drains precious energy resources and expels waste heat to the surroundings.

Modern architectural styles in temperate climates have largely dictated the aesthetics of these new houses on the urban fringes. Figure 1 provides a snap shot of the obvious changes that have occurred in the design of semi-rural housing in Malaysia. The vernacular house in Figure 1a was designed to create a shaded, well-ventilated enclosure with a pitched roof that quickly shed rain water. Wall cladding and floor surfaces were made of spaced timber planks. This allowed substantial ventilation [4]. However, the interior tended to be dark as there was no glazing in the windows, only window shutters. When the shutters were closed, the only natural light came through the chinks between the wall planks. Although, over the second half of the twentieth century, steel roof sheeting, concrete blocks and cement sheets have gradually replaced thatched roofs and carved timber walls and shutters, the principles of shading, fast shedding of water and cross ventilation remained, as seen in Figure $1 b$. However, the most recent designs of project homes do not reflect the needs of a tropical environment with more cellular internal spaces that limit cross ventilation. In addition, there are extensive unshaded areas of glazing and low pitched roofs [5]. A typical example can be seen in Figure 1c. 
Figure 1. The move from vernacular housing to 21 st century project home. (a) Vernacular housing (reproduced from [6] with author's permission); (b) Existing typical housing in Sarawak (V. Lai, pers. collection); (c) New typical house designs_-Sarawak [7].

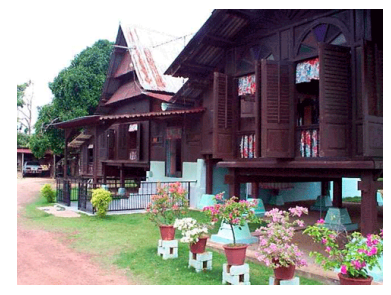

(a)

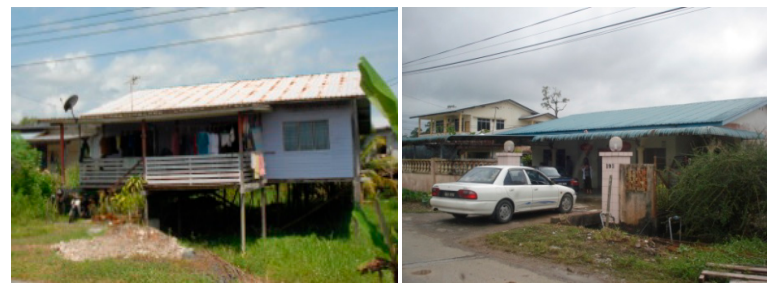

(b)

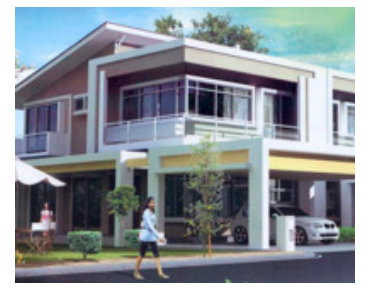

(c)

\section{Research Approach}

A review of literature $[2,4,5,8,9]$ indicated that a substantial amount of research has been directed at thermal comfort and climatic design in the tropics. The outdoor/indoor transitional space or verandah has been of particular interest. Some researchers [5,8] emphasize the importance of shaded outdoor spaces that enable both social interaction and a reduction in demand for air-conditioned indoor space whilst also shading external walls. Others [9] refer to the importance of cross ventilation and the role of ceiling fans in the tropics. However, this research has not been well linked to the impact of urbanization on housing design in developing countries in the tropics.

This paper argues that this linkage should be made. There is a relationship between design in the tropics and reduced need for air-conditioning. There is also a relationship between climatic design and lifestyle changes, changes in housing density, changes in construction materials, and people's expectations of new housing on the urban periphery. Using the available literature to identify building design elements required to improve thermal comfort in the tropics, the paper goes on to identify other design elements needed to respond to those particular changes occurring on the urban fringe of tropical cities. This enables the authors to develop consolidated design strategies that could be utilized in the development of project homes on the periphery of urban centres in the tropics.

It was considered appropriate to use a case study approach to test these design strategies. Yin [10] suggests that this methodology is appropriate for examining a contemporary phenomenon in its real-life context, where "how" and "why" type questions are being investigated. Thus, a set of design strategies was applied to a prototype house on a particular block of land in Tapah, a village on the periphery of Kuching, Sarawak, where rapid urbanization is occurring.

The prototype house was simulated using AccuRate v.1.1.4.1, a software package acknowledged in the Building Code of Australia [11] as appropriate to determine thermal performance. The simulation results were compared with thermal comfort levels.

At an informal workshop, the prototype was exposed to comment from a number of villagers in Tapah. Subjective responses provided a basis on which to better understand the local people's current expectations of new housing.

\section{Thermal Conditions and Changing Lifestyles in the Tropics}

As mentioned above, the types of housing being constructed on the fringes of cities in Malaysia are changing significantly. This study examined such factors as changes in lifestyle, communal activity, 
density, and construction practices that are related to urbanization on the outer fringes of Kuching and are influencing housing. As climatic features and their relationship to thermal comfort form the backdrop for climatically sensitive design, this section starts with a summary of the climate in Kuching and considers the meaning of thermal comfort in that location.

\subsection{Climatic Features in Kuching}

Kuching has a tropical climate, meaning it is typically hot and humid throughout the year. There are minor seasonal and local variations, but the overriding need is to avoid solar gain and maximize possibilities for air movement.

Kuching has a latitude of $1.3^{\circ} \mathrm{N}$, longitude of $110.4^{\circ} \mathrm{E}$ and an altitude of $27 \mathrm{~m}$ above sea-level. Monsoonal winds vary during the year. According to the Malaysian Meteorological Department [12], the southwest monsoon (from May to September) brings drier conditions and causes average temperatures to be approximately $2 \mathrm{~K}$ hotter during the day than during the rest of the year, as seen in Figure 2 . The northeast monsoon period, from November to March, brings heavy rains, high relatively humidity, and slightly lower air temperatures [13].

Figure 2. Monthly air temperatures for Kuching [11].

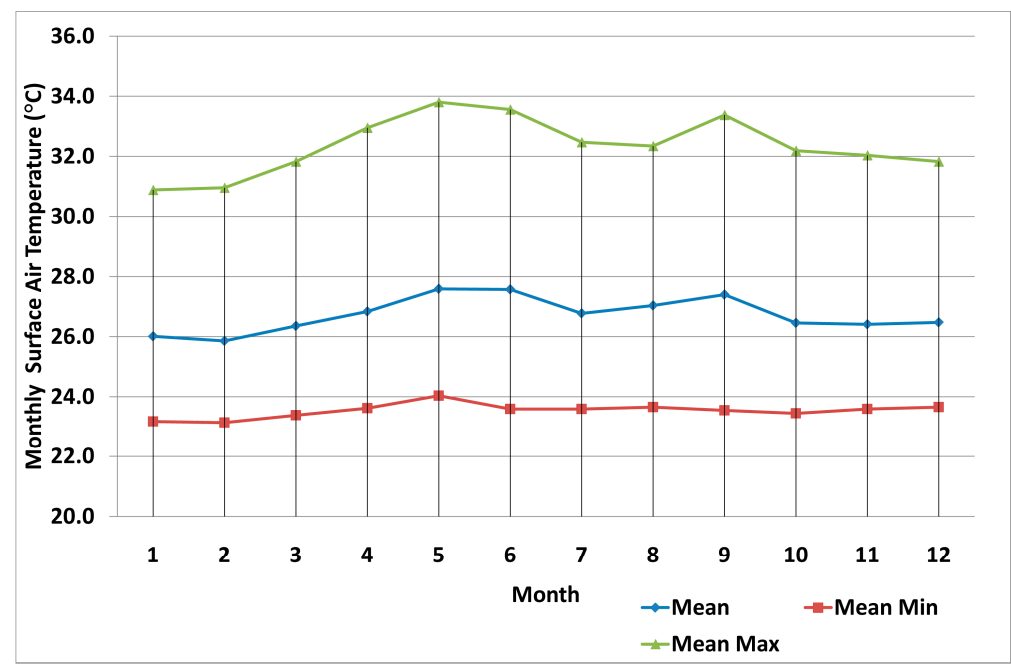

As Kuching is almost on the equator, the sun path is similar on both northern and southern aspects of a building. Consequently, shading is necessary to all four façades of a building.

Wind speeds are generally low in tropical regions except when there are thunderstorms. The mean wind speed in Kuching is generally at $1.4 \mathrm{~m} / \mathrm{s}$, thus, it is important to have ventilation strategies that encourage cross ventilation regardless of orientation to prevailing wind. Thus openings on opposite sides of rooms are highly desirable for air movement [14]. However, when the outdoor air is hotter than the interior air, it is useful to minimize air intake, and facilitate indoor air movement through the use of ceiling fans.

\subsection{Thermal Comfort}

According to Auliciems and Szokolay [15], there are four environmental factors that contribute to any assessment of human thermal comfort. They are indoor temperature, thermal radiation, humidity, 
and air speed. Further, in assessing thermal comfort in non-air-conditioned buildings, researchers, such as de Dear and Schiller-Brager [16] and Humphreys and Nicol [17], have established a strong correlation between outdoor meteorological conditions and perceptions of thermal comfort. This is referred to as an adaptive approach to thermal comfort. Humphreys and Nicol's adaptive approach to thermal comfort was based on a quality-controlled database from thermal comfort field studies worldwide. Approximately 21,000 observations from 160 buildings were included in the database. The statistical analysis of the database showed that, within certain limits, people adapt their thermal comfort expectations to their climatic and cultural environment. Humphreys and Nicol [17] suggest that the optimum comfort temperature $\left(\mathrm{T}_{\mathrm{c}}\right)$ depends on mean monthly outdoor temperature $\left(\mathrm{T}_{\mathrm{o}}\right)$ in accordance with the following equation:

$$
\mathrm{T}_{\mathrm{c}}=13.5+0.54 \mathrm{~T}_{\mathrm{o}}
$$

There are limitations to using this equation, which include the assumptions that people are wearing clothing of their choice, they are sedentary or engaged in light activity, there is slight air movement, and the outdoor monthly mean temperature $\left(\mathrm{T}_{\mathrm{o}}\right)$ is within the range of $10{ }^{\circ} \mathrm{C}$ to $33{ }^{\circ} \mathrm{C}$. In addition, the width of the comfort zone around the optimum comfort temperature could be at least $+2 \mathrm{~K}$ or -2 $\mathrm{K}$ [17]. Researchers [17-19] have discussed the cooling effects of air movement on thermal comfort in non-air-conditioned buildings. A consensus of these researchers' views suggests that an indoor air movement of $1.5 \mathrm{~m} / \mathrm{s}$ to $2 \mathrm{~m} / \mathrm{s}$ will have a cooling effect of approximately $3 \mathrm{~K}$, provided the air temperature is below a maximum of approximately $33^{\circ} \mathrm{C}$. Ceiling fans can readily produce this sort of air movement.

Equation 1 was used to determine an optimum comfort temperature range in Kuching, from $27.8^{\circ} \mathrm{C}$ to $28.7^{\circ} \mathrm{C}$ (Figure 3). Using the band width of $2 \mathrm{~K}$, as suggested by Humphreys and Nicol [17], and an additional $3 \mathrm{~K}$ due to the possibility of having ceiling fans in the tropics, the maximum thermal comfort temperatures could be as high as $33{ }^{\circ} \mathrm{C}$. In the tropics in non-air-conditioned buildings, a minimum comfort temperature is not relevant in housing, as occupants can put on additional clothing for warmth.

Figure 3. Maximum thermal comfort temperature compared to outdoor temperature in Kuching.

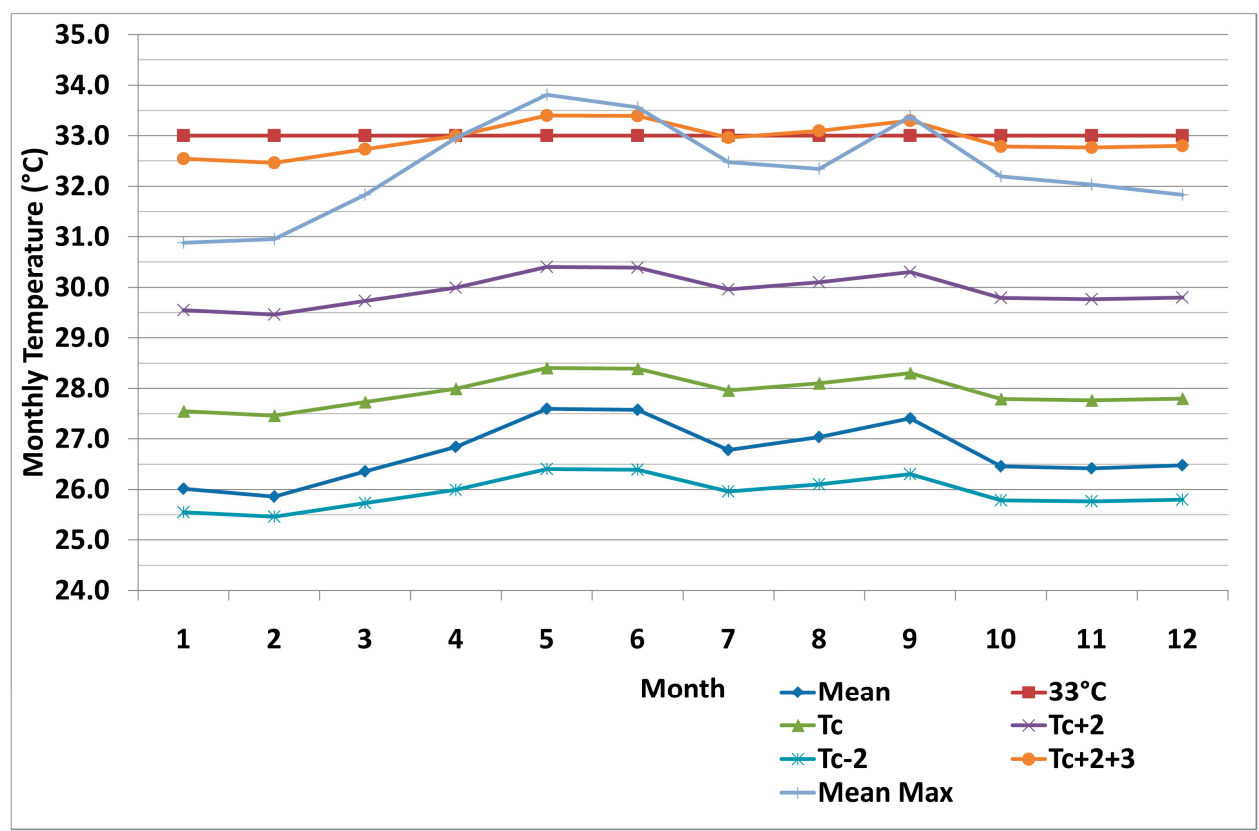




\subsection{Changes in Lifestyle and Communal Activity}

The lifestyle of the rural population in Sarawak is changing to reflect the urbanization of economic activities. Economic activities have dramatically changed from agricultural production to commercial activities since Sarawak joined the Federation of Malaysia [20,21]. Consequently, less time is available to maintain houses built from traditional materials. Materials such as timber and thatched roofs are high maintenance and, thus, are not suitable for the current needs of society, despite performing well climatically [22]. Instead, less maintenance-intensive materials such as reinforced concrete, rendered bricks, concrete blocks and metal roofing are favoured. However, there seems to be no consideration given to how these newly adopted materials influence the character of the built environment or respond to the tropical climate [23].

In the past, there were regular communal activities within a residential area. Villagers would congregate for daily agricultural activities or festivals and celebrations. This sense of communal living helped to reduce criminal activities and increased neighbourly tolerance [20]. Thus, security of the home was not a major issue.

However, as urbanization occurs and more time is spent in commercial work away from home, there is less time for communal activities. This decrease in community involvement has led to a reduction in neighbourly trust and a need for greater privacy [24]. Both visual and acoustic privacy has become more important. Consequently, for both safety and privacy, houses tend to be more enclosed [20].

Verandahs, patios, and courtyards are traditionally the semi-private places near the entry where visitors are engaged before being invited inside the house to the living room and dining room [8]. However, these semi-private spaces are being taken over by carports, thus, forcing greater use of indoor space.

\subsection{Changes in Density and Construction Practice}

Typically, villages consist of clusters of free-standing houses on large lots with surrounding agricultural land. However, this rapidly changes when a village is redeveloped. Either free standing houses are built on smaller blocks of land of between 600 to 900 square metres, or row houses are constructed on even smaller lots of 250 to 450 square meters [5].

The typical new building practice in Malaysia is concrete-framed construction with brick infill walls. Reinforced concrete is formed into columns and beams, which act as the structural frame. Any space that needs to be formed into a wall is filled with a single skin of brickwork, which is typically $100 \mathrm{~mm}$ thick, or glass. Interior walls are finished with gypsum plaster while the exterior walls have a sand and cement render [5]. In some instances ceiling fans are being provided but this is not required.

\section{Design Elements and Design Strategies}

\subsection{Design Elements}

Within the constraints of current concrete-framed construction practice in Kuching there are three design elements that are fundamental to successful climatic design in the tropics. They are 
appropriate shading, cross ventilation, and significant roof insulation. The impact of each element is summarized below.

Shading has slipped from the consciousness of housing developers, as they assume all houses will be air-conditioned. When external walls are continuously exposed to the tropical sun, they heat up even if the best reflective paint is applied. Lin [25] established that shading strategies for walls are critical, as they are more effective in keeping solar heat gain out of a house than wall insulation. Furthermore, in tropical climates where the diurnal temperature range is small, there is little opportunity for walls that have been heated by the sun to cool down enough to be useful as thermal mass for indoor heat stabilization.

Lin [25] also demonstrated in his study that in a tropical climate, cross ventilation from natural breezes can be utilized for cooling $25 \%-45 \%$ of the total time. In Kuching, the mean wind speeds are approximately $1.4 \mathrm{~m} / \mathrm{s}$. This wind velocity can aid cross ventilation, but it is more important to exploit the pressure differential between the windward and leeward side of a building so that air movement can occur at very low air velocities [26]. Therefore, it is important that designs in Kuching have openings on opposite sides of a space to encourage all air movement.

Ceiling fans also facilitate air movement, which enhances personal thermal comfort [12]. In regard to ceiling fans, it is important to remember that low ceiling heights make the installation of ceiling fans unsafe.

Solar radiation on the roof can lead to significant indoor temperature rise. One of the most useful strategies to avoid this is to adequately insulate the roof and/or ceiling space. A total roof/ceiling thermal resistance level of at least R4.6 is recommended for housing with pitched roofs and ventilated ceiling spaces in tropical areas [11].

\subsection{Consolidated Design Strategies}

The following design strategies have been developed based on the various needs that arise from changes in lifestyle and needs for shading and natural ventilation. It is recognized that higher density increases the need for privacy, which may conflict with the need for natural ventilation.

A relatively free flowing design is needed for natural ventilation to function well with the location and size of openings being determined so that air flow passes through those spaces most frequently occupied $[27,28]$. However, privacy needs to be considered when locating external openings. Thus, openings onto semi-open space such as a patio or verandah are most desirable, as such, spaces are well ventilated but also provide a buffer zone in terms of privacy. As external openings improve ventilation but reduce visual and acoustic privacy as well as security, privacy screens and security grills are frequently required [29]. These elements could provide a design opportunity for cultural expression as well as fixing points for insect screens.

Adjustable glass louvres can be successfully used to control the degree of opening in a window, as they can provide a much larger open area when compared to other types of window openings. This type of window still allows ventilation even when partially closed during rainy periods.

Opaque louvres can be used at high and low levels to provide openings for natural ventilation, even when glazed openings are closed for privacy purposes. Ceiling spaces can be ventilated through the use of fixed louvres to remove accumulated hot air [26,30]. 
As for shading, walls should be fully shaded from direct sunlight, whilst not prohibiting the free movement of air. Therefore, angled louvre-type shading is one of the best ways of providing shading whilst still enabling the free flow of air [27]. The most efficient louvre can be designed according to the solar angles of each site, although fully adjustable louvres are the most desirable.

Horizontal shading devices are recommended for north- and south-facing openings, while vertical shading devices are recommended for west- and east-facing openings. Whenever possible, these shades should have multiple usages - to create verandahs, pergolas for plants, vertical planters, or light shelves [31].

In circumstances where shading of walls is difficult, non-habitable rooms can be located to act as buffer zones. Non-habitable rooms such as storerooms, toilets, showers, and spaces like balconies, car ports, and verandas, can all serve as buffer zones. Furthermore, sunlight and ventilation is welcomed in wet areas such as laundry, toilet and bathroom, to reduce mould growth.

Vegetation can be utilized both as shading and to reduce reflected sunlight from the surrounding landscape [26,28]. Vegetables and fruiting trees can be planted to provide food and possible additional income from sales of the produce. Shading of inflowing air can be utilized so that the intake air is cooler than the surroundings that are exposed to the sun. However, it is also important that landscaping does not obstruct available breezes.

Defensive plants such as different species of aloes, bougainvillea and cacti can serve as deterrents to thieves when planted next to openings, while providing shading to lower parts of walls that may not be covered by horizontal shadings. Whenever possible, local plant species should be used, as they adapt well to the climate and can provide a natural environment for the local flora and fauna to flourish [32].

Twelve design strategies were formulated in order to develop a prototype family home in a village on the outskirts of Kuching. They are:

(1) cultural appropriateness

(2) ventilation openings on opposite sides of rooms

(3) semi-open space to provide privacy buffer and engage visitors

(4) high ceiling of at least $2.7 \mathrm{~m}$ to accommodate ceiling fans

(5) adjustable screens on openings to allow for views and adequate indoor daylight

(6) shadings to all thermal mass external walls

(7) adjustable and fixed louvres for ventilation

(8) non-habitable rooms as sunlight buffers

(9) extensive use of vegetation as shading

(10) high levels of roof/ceiling insulation

(11) use of current local standard modern construction materials

(12) possibility to efficiently air-condition some spaces.

\section{Case Study to Test Design Strategies}

The case study proposes a prototype family home at Tapah Village on the urbanizing periphery of Kuching. Tapah is a village of approximately 10,000 people that is undergoing significant change [33].

The site chosen is highlighted in Figure 4. It is a typical lot of 900 square metres in a typical street in Tapah Village. Usually, on such a block, a detached double story residence would be built by 
mainstream developers. The size of such residences ranges from 290 square metres to 450 square metres, with a configuration of three to five bedrooms and three to four bathrooms [34], as shown in Figure 5. This model provided the outline for a design brief for a prototype house although without a separate maid space.

Figure 4. Location of site in Tapah Village [35].

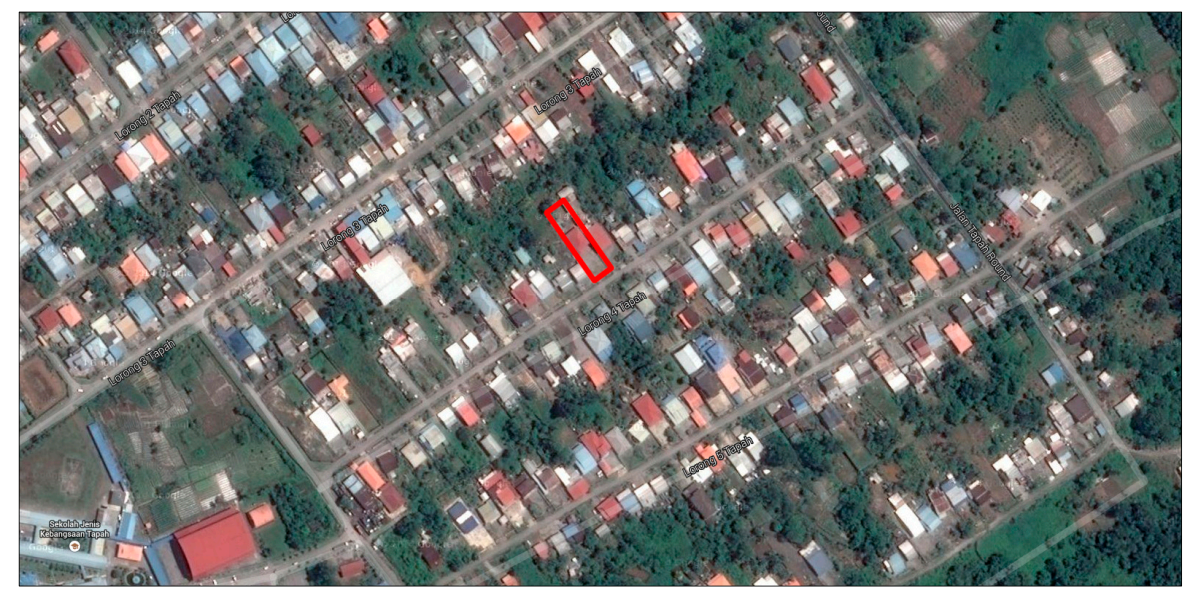

Figure 5. Typical project house with ground and first floor (total area $297 \mathrm{~m}^{2}$ ) [34].
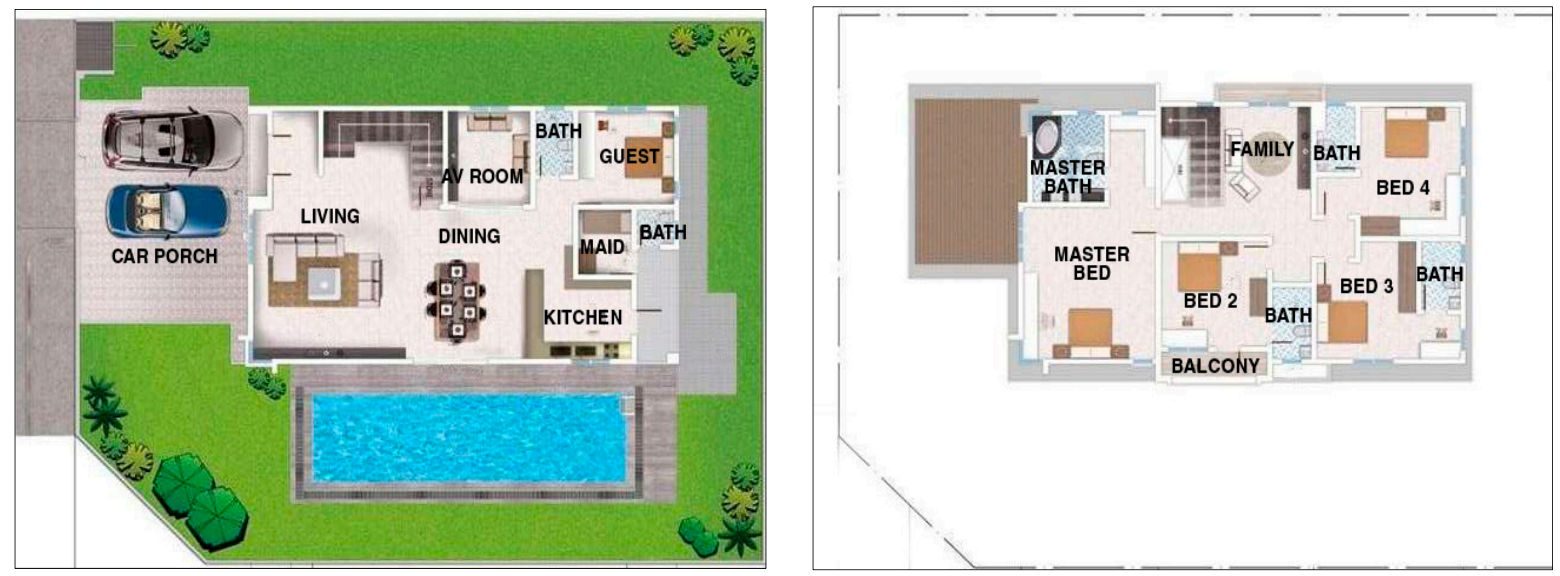

\subsection{Prototype Design}

The prototype house incorporated the consolidated design strategies in the early stages of the design process. It was to have a floor area similar to that of a typical mid-range project home. Furthermore, it was to have similar room layouts to a project home with one bedroom on the ground floor while the remaining bed rooms were on the first floor. A noticeable difference though is that the upstairs bedrooms share a bathroom and toilet rather than providing a separate bathroom for each bedroom as in the project home. The prototype adopts the local building method of using a reinforced concrete frame with infill brick walls and provides for the installation of air conditioning in the bedrooms should that be required.

There are limited provisions for cross ventilation in the project home, as most rooms only have one external opening. The prototype creates openings on opposite sides of all habitable rooms to encourage cross ventilation. Additionally, all external openings are shaded by screens, which can be adjusted to 
suit privacy needs and daylight needs. These screens are fixed or adjustable louvres that enable cross ventilation to occur even if doors are shut for reasons of security or privacy. In addition, sufficient ceiling height was provided in the prototype to accommodate ceiling fans on both levels.

For the prototype, cultural appropriateness was addressed by arranging large living spaces on both lower and upper levels for family activities. Semi-private areas such as a patio and balcony are used as interface spaces between private and public areas.

To reduce heat transfer to habitable spaces, all thermal mass external walls are shaded. Services areas such as toilets, ensuite, storage, laundry, and kitchen are also used as buffer zones to minimize heat transfer to habitable spaces. Existing trees are preserved where they will provide shade to the thermal mass of the house. The roof and ceiling are insulated to reduce heat transfer through the roof.

The elevation, floor plans and section in Figures 6-8 show how the design strategies have been applied in the prototype house. The numbers used in the plans and section relate to the 12 design strategies formulated above.

Figure 6. Prototype house elevation.

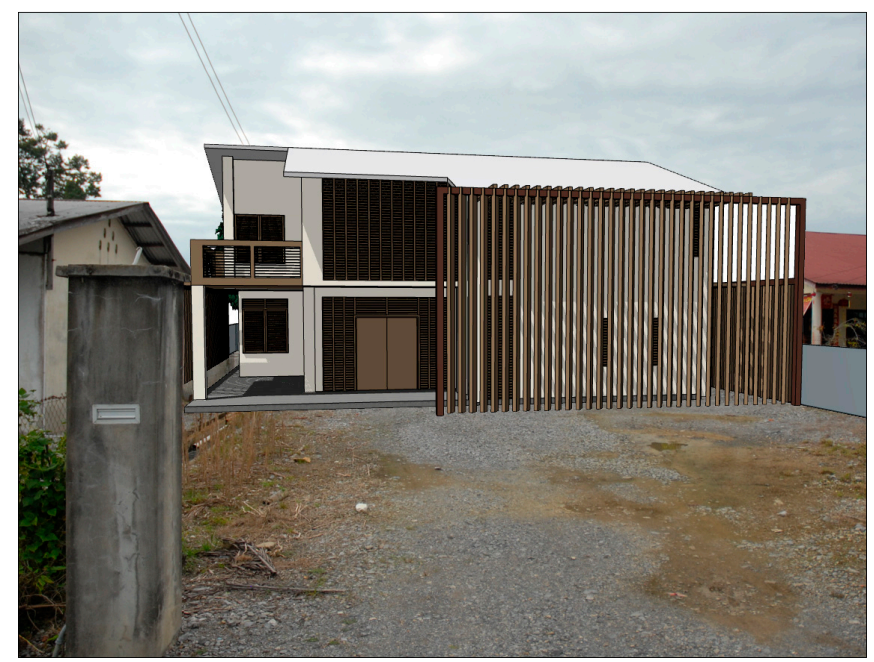

Figure 7. Prototype house plans.
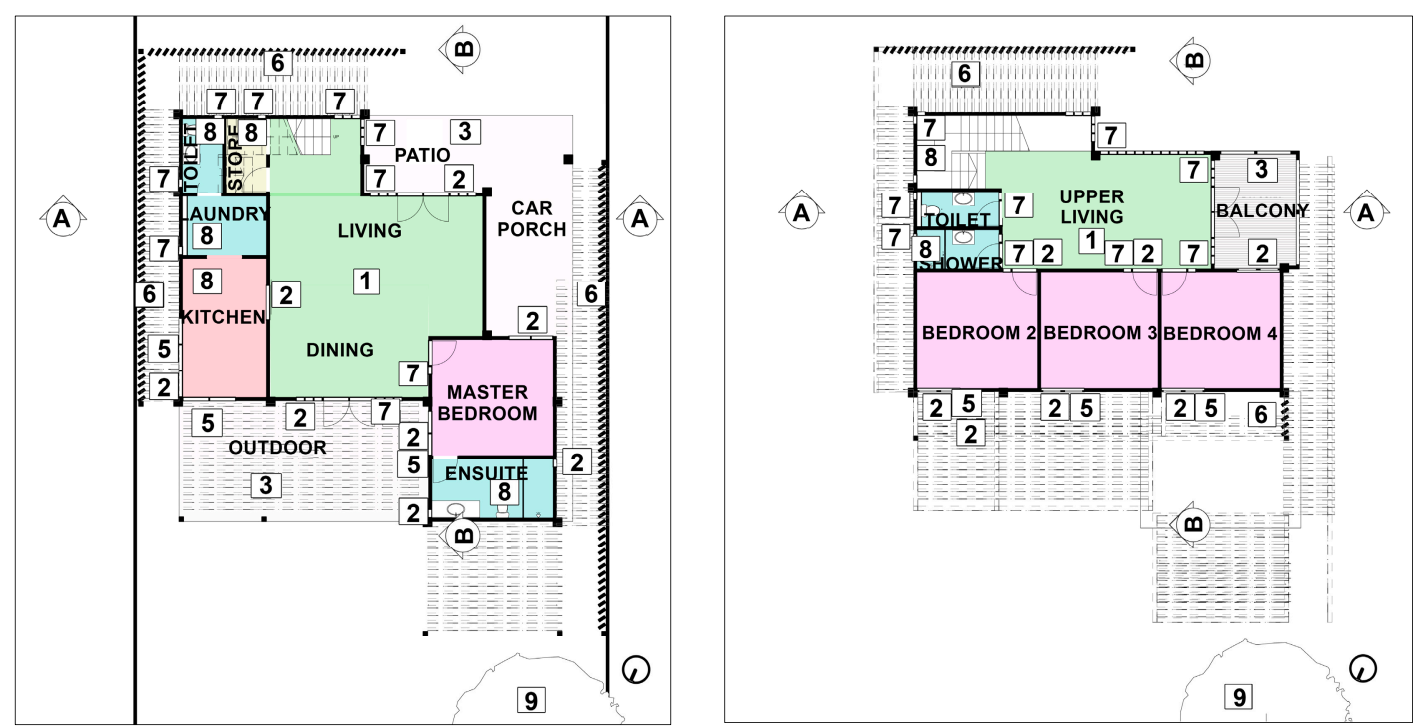
Figure 8. Prototype house section.

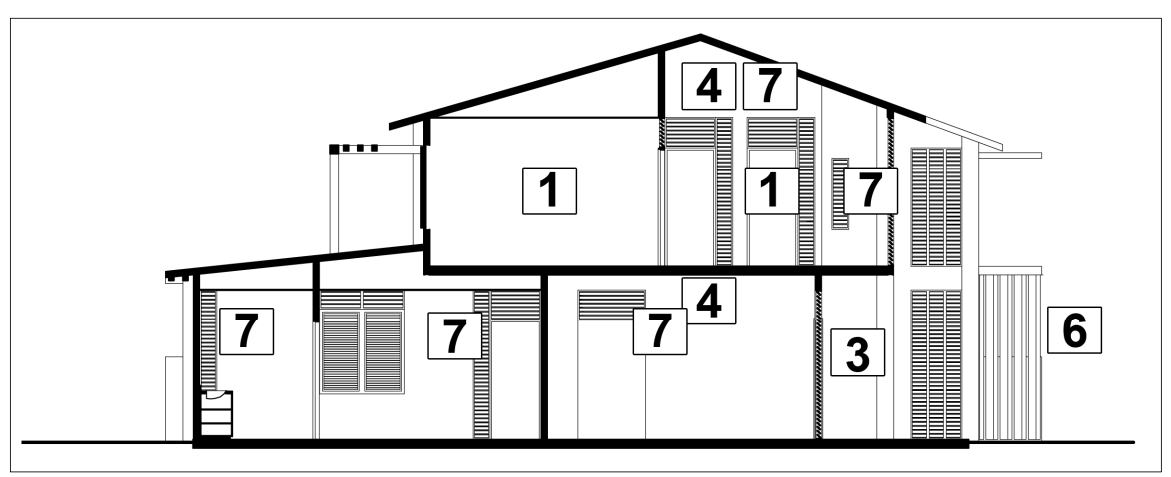

Standard building practice in Tapah was applied to the proposal, with the following proposed adjustments:

- Full height glass-louvered windows with security bars for openings that open up to an outdoor living area.

- Roof is insulated first with a top layer of reflective foil and then bulk insulation of R4.6, to meet current Building Code of Australia [11] provisions in the worst case scenario if the upper surface of the roofing material is a dark colour.

- Ceiling spaces are generally ventilated through the use of twin vents. As there is no ceiling space above the upper floor living area, heated air that passes into the space from the bedrooms is discharged through the screened walls.

- Internal doors have high level vents that can be closed when privacy is needed or opened while the door is closed to provide cross ventilation.

- While newly planted trees reach maturity, temporary shade structures are provided.

- $\quad$ Louvered windows with shading screens are provided to all bedrooms.

\subsection{Thermal Performance of Prototype}

The prototype house design was simulated using AccuRate v.1.1.4.1 [36] to establish indoor temperatures during the hottest week in the hottest month. The climatic data used was obtained from the Malaysian Meteorology Department (Sarawak Division). That data was converted into AccuRate format and inserted into the weather folder as a ._climat01.TXT file which could be used for the thermal simulation.

The results of the simulation during these extreme weather conditions (Figure 9) show how indoor temperature in the main ground floor living area and in a first floor bedroom tracks the changes in outdoor temperatures. As all spaces are well ventilated and externally shaded, indoor temperatures always remain lower than outdoor temperatures even in extreme conditions.

Figure 9 highlights that for a very short time ( $5 \mathrm{~h}$ in total) on three consecutive days when external temperatures reach approximately $35^{\circ} \mathrm{C}$, the living room temperature exceeds the maximum comfort temperature of $33{ }^{\circ} \mathrm{C}$. However, the temperatures in Bedroom 3 remain below $33{ }^{\circ} \mathrm{C}$ at all times. 
Figure 9. Temperature Simulation of Design Prototype.

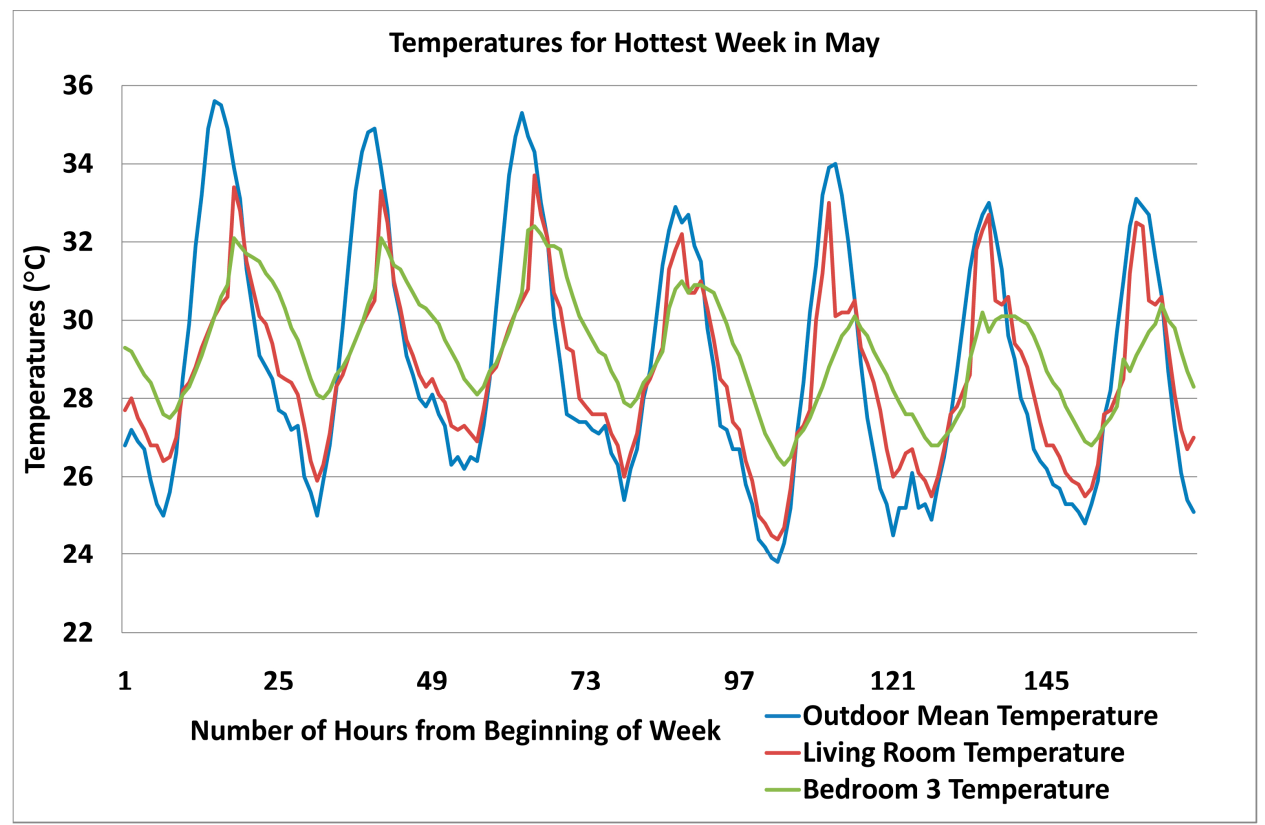

\subsection{Social Acceptance}

Acknowledging that designers cannot unilaterally change public perception of housing, an informal workshop was organized in Tapah by one of the authors in July 2012. The aim was to elicit responses regarding the acceptability of new housing that was different to typical new project homes. The village leader and nine other adult villagers from various age groups (working adults to retirees) were asked the following two questions based on the drawings of the prototype:

(1) Would you like to live in a house with this layout and this appearance?

(2) Would you like to live in a house that has ceiling fans and remains reasonably cool without air-conditioning?

The general feedback was that the house was acceptable provided that the extensive exterior shading would not obstruct significant views nor decrease the amount of daylight entering the house. In addition, there was concern expressed about the cost of the shading devices.

The villagers also were clear that they wanted to have options to open or close the windows and the shading screens to control the amount of light and ventilation. Traditional unglazed openings and timber shutters were not an acceptable option. Further, the villagers wanted to have the choice of setting up air-conditioned spaces if they chose.

\section{Discussion and Significance}

Rapid urbanization has led to a rush in housing development on the outskirts of cities in the tropics. These developments lack both sensitivity to local expectations and an appropriate design response to the climate.

This paper describes twelve design elements for inclusion in climatically and socially appropriate housing design in tropical environments. Although it is not a complete study of the possibilities of sustainable architecture in Kuching, Sarawak, it is a starting point to demonstrate how architectural 
elements can serve to provide a culturally sensitive, thermally-comfortable house that does not need regular use of air-conditioning to be comfortable. Even though the design principles have only been tested on a bungalow house, it is anticipated that they could creatively be applied to other forms of housing such as row housing. As it is recognized that architects cannot dictate the lifestyle of building occupants, it is acknowledged that any design must enable the installation and efficient use of air-conditioning even if it is not necessary for thermal comfort.

Currently, major housing developers in Sarawak do not consider climatic design a viable financial proposition, particularly as it relates to shading and cross ventilation [37]. Shading devices are considered expensive, either having a high capital cost when made of aluminium or a high maintenance cost when made of timber. Climatically appropriate features such as wide eaves and louvered openings are seen as additional costs that do not justify their incorporation into a built project. It is cheaper for a developer to install air conditioning and ignore the ongoing energy expenses for the occupants. In addition, the public has now been educated to believe that air conditioning is a symbol of social advancement and is essential for well-being [8]. However, there is no evidence that continuous use of air conditioning improves well-being compared to climatically sensitive design with occasional use of air-conditioning.

\section{Conclusions}

Continual evaluation of the needs of the local people is needed to provide appropriate housing in a society. This is particularly true when life style is undergoing radical changes, as it is on the fringes of tropical cities. Prototype housing should be tested before it is imposed so that it is appropriate for its contexts.

From the current research, it is clear that tropical design elements can be readily incorporated in bungalow houses to provide thermal comfort with minimal use of air conditioning. Such designs have two primary benefits - the need for air conditioning is minimised and the housing expresses a local character. Currently developers take a "quick fix" approach to housing in rapidly urbanizing areas in the tropics. They ignore the climate and impose a generic house design in a variety of climatic zones. This paper suggests this is not in the best interest of those living in housing on the urban fringes of tropical cities.

The current research points to the need for further research in two associated areas. Firstly, what is the impact on wellbeing and the environment when people in the tropics must depend on air conditioning to make their homes livable? Secondly, what design elements are required in the other popular types of housing that are becoming prevalent on the urban fringes of tropical cities?

\section{Author Contributions}

The research was jointly designed by both authors. Vincent Voon Chin Lai performed the research under the supervision of Elizabeth Karol. Both authors analyzed the data and wrote the paper. Both authors read and approved the final manuscript.

\section{Conflicts of Interest}

The authors declare no conflict of interest. 


\section{References}

1. Department of Economic and Social Affairs of United Nations. World Urbanization Prospects: The 2011 Revision. Available online: http://esa.un.org/unup/pdf/WUP2011_Highlights.pdf (accessed on 31 January 2013).

2. Koenigsberger, O.H.; Ingersoll, T.G.; Mayhew, A.; Szokolay, S.V. Manual of Tropical Housing and Building Part One: Climatic Design; Longman: London, UK, 1974.

3. Goad, P.; Ngiom, L.T. Recent Malaysian Architecture; Pesaro Publishing: Singapore City, Singapore, 2007.

4. Hassan, A.S.; Ramli, M. Natural Ventilation of Indoor Air Temperature: A Case Study of the Traditional Malay House in Penang. Am. J. Eng. Appl. Sci. 2010, 3, 521-528.

5. Hanafi, Z. Housing Design in relation to Environmental Comfort-A Comparison of the Traditional Malay House and Modern Housing. Build. Res. Inf. 1994, 22, 21-33.

6. Van Wijnen, B. Malay Houses. Available online: http://www.malaysiasite.nl/malayhouse.htm (accessed 18 March 2014).

7. Shin Yang Sdn Bhd. Greenville-Double Storey Semi-Detached House (Phase 5), Miri. Available online: http://www.shinyang.com.my/images/joomgallery/thumbnails/properties_for_ sale_7/greenville_-_double_storey_semi-detached_house_phase_5_miri_26/photo_20121123_ 1694074376.jpg (accessed on 18 March 2014).

8. Zin, M.H.M.; Ibrahim, N.L.N.; Zain, M.F.M.; Jamil, M. The Social and Environmental Roles of Verandah in Tropical Houses. Int. J. Soc. Manag. Econ. Bus. Eng. 2012, 6, 311-313.

9. Md Zain, Z.; Taib, M.N.; Mohd Shah Baki, S. Hot and Humid Climate: Prospect for Thermal Comfort in Residential Building. Desalination 2007, 209, 261-268.

10. Yin, R.K. Case Study Research: Design and Methods, 3rd ed.; Sage Publications: Thousand Oaks, CA, USA, 2003.

11. Australian Building Codes Board. The Building Code of Australia; SAI Global: Sydney, Australia, 2014; Volume 2.

12. Malaysian Meteorological Department. Sarawak. Available online: http://www.met.gov.my/ index.php?option=com_content\&task=view\&id=50\&Itemid=1340 (accessed on 18 March 2014).

13. Abdullah, N.A.; Shuhaimi, S.H.; Toh, Y.Y.; Shafee, A.H.; Maznorizan, M. The Study of Seasonal Variation of PM10 Concentration in Peninsula, Sabah and Sarawak; Malaysian Meteorological Department: Petaling Jaya, Malaysia, 2011.

14. Aynsley, R.M.; Melbourne, W.; Vickery, B.J. Architectural Aerodynamics; Applied Science Publishers: London, UK, 1977.

15. Auliciems, A.; Szokolay, S. Thermal Comfort; Passive and Low Energy Architecture in Association with University of Queensland: Brisbane, Australia, 1997.

16. De Dear, R.; Schiller-Brager, G. Developing an Adaptive Model of Thermal Comfort and Preference. ASHRAE Trans. 1998, 104, 1141-1152.

17. Humphreys, M.; Nicol, J.; Outdoor Temperature and Indoor Thermal Comfort: Raising the Precision of the Relationship for the 1998 Ashrae Database of Field Studies. AHSRAE Trans. 2000, 206, 485-492.

18. Fountain, M. An Empirical Model for Predicting Air Movement Preferred in Warm Office Environments. In Standards for Thermal Comfort: Indoor Air Temperature for the 21st Century; Nicol, F., Humphreys, M., Sykes,O., Roaf, S., Eds.; E \& F. N. Spon: London, UK, 1995. 
19. Givoni, B. Climate Considerations in Building and Urban Design; Van Nostrand: New York, NY, USA, 1998.

20. Tettoni, L.I.; Edric, O. Sarawak Style; Times Editions: Singapore City, Singapore, 1996.

21. Razani, J.; Stillwell, J.; Rees, P. The changing Pattern of Rural and Urban Migration in Malaysia. In Proceedings of the Third International Population Geographies Conference, University of Liverpool, Liverpool, UK, 19-21 June 2006.

22. Koenigsberger, O.; Lynn, R. Roofs in the Warm Humid Tropics; Lund Humphries: London, UK, 1965.

23. Crinson, M. Modern Architecture and the End of Empire; Ashgate Publishing: Hants, UK, 2003.

24. Sendut, H. Contemporary Urbanization in Malaysia. Asian Surv. 1966, 6, 484-491.

25. Lin, H.-T. Policy and evaluation system for green building in subtropical Taiwan. In Tropical Sustainable Architecture: Social and Environmental Dimensions; Bay, J.-H., Ong, B.L., Eds.; Architectural Press: Oxford, UK, 2006; pp. 101-124.

26. Szokolay, S.V. Introduction to Architectural Science: The Basis of Sustainable Design; Architectural Press: Oxford, UK, 2004.

27. Kukreja, C.P. Tropical Architecture; Tata McGraw-Hill Publishing: New Delhi, India, 1982.

28. Bromberek, Z. Eco-Resorts: Planning and Design for the Tropics; Architectural Press: Oxford, UK, 2009.

29. Tan, H.B. Tropical Architecture and Interiors: Tradition-Based Design of Indonesia, Malaysia, Singapore, Thailand; Page One Publishing: Singapore City, Singapore, 1994.

30. Ahmad, A.M. On Ceiling Heights and Human Comfort. In Building in Hot Climates: A Selection of Overseas Building Notes; Overseas Division of the Building Research Establishment, Ed.; Department of Environment: London, UK, 1974; pp. 391-397.

31. Hyde, R. Climate Responsive Design: A Study of Buildings in Moderate and Hot Humid Climates; E \& F. N. Spon: London, UK, 2000.

32. Yeang, K. Ecodesign: A Manual for Ecological Design; John Wiley \& Sons: London, UK, 2006.

33. Du, M. History of Tapah Village Chinese Primary School. Available online: http://www.intimes. com.my/huaxia/06huaxia14.htm (accessed on 18 March 2014).

34. iProperty.com. Cypress Residences (Double Storey Bungalows). Available online: http:// newlaunch.iproperty.com.my/Cypress-Residences-(-Double-Storey-Bungalows)/2214\#review/ (accessed on 17 March 2014).

35. Google Map. Tapah Village, Sarawak. Available online: http://map.google.com (accessed 18 March 2014).

36. Department of Industry Australia. NatHERS Accreditated Software. Available online: http://www.nathers.gov.au/accredited-software/nathers-accredited-software (accessed on 18 March 2014).

37. Abidin, N.Z. Investigating the Awareness and Application of Sustainable Construction Concept by Malaysian Developers. Habitat Int. 2010 34, 421-426.

(C) 2014 by the authors; licensee MDPI, Basel, Switzerland. This article is an open access article distributed under the terms and conditions of the Creative Commons Attribution license (http://creativecommons.org/licenses/by/3.0/). 